\title{
Early versus late proning in non-intubated COVID-19 pneumonia
}

\author{
Vijo Poulose 1* $^{*}$
}

In a recent issue of Critical Care, Kaur et al. published an interesting study comparing the outcomes of early (EP) vs late proning on awake, non-intubated COVID-19 patients with hypoxemic respiratory failure [1]. The study is a post hoc analysis of a meta-trial on awake proning in COVID-19 pneumonia, which was published in August 2021 issue of the Lancet [2]. This "meta trial" (a novel trial design) of 6 randomised, controlled trials involved 6 nations and 1126 patients and showed that proning (versus standard care) reduced the need for intubation, but had no effect on mortality.

The primary outcomes in the Kaur study were 28-day mortality and intubation rates. The results showed that EP had a substantial mortality benefit (26\% vs $45 \%)$, but with no difference in intubation rates.

Now this raises a question which the authors did not elaborate on. If EP is so effective in reducing mortality, why did it not lower intubation rates? The primary benefit of proning (as compared to supine position) is achieving better oxygenation via a variety of proposed mechanisms (better pleural pressure gradients, less weight of the heart and abdominal contents, more uniform perfusion). If EP helps in the initial exudative phase of ARDS (as the authors theorize), why did it not provide an intubation benefit?

One has to assume that all or most of the cases in the EP arm that needed intubation had worsening respiratory failure. Can this slightly confusing message be attributed

This comment refers to the article available online at https://doi.org/10.1186/ s13054-021-03589-3.

*Correspondence: Poulose.vijo@singhealth.com

${ }^{1}$ Respiratory and Critical Care Medicine, Changi General Hospital, 2, Simei

Street 3, Singapore 529890, Singapore to the inherent weaknesses of a post hoc analysis and the fact that being a small sample size (125 patients), the trial was probably underpowered?

I look forward to hearing from the authors for further clarification.

\section{Authors' reply to “Early versus late proning in non-intubated COVID-19 pneumonia"}

\author{
Ramandeep Kaur ${ }^{2}$, J. Brady Scott² ${ }^{2}$ David L. Vines ${ }^{2}$ and \\ Jie Li $i^{2}$ \\ *Correspondence: sgJie_Li@rush.edu \\ ${ }^{2}$ Department of Cardiopulmonary Sciences, Division of Respiratory Care, \\ Rush University Medical Center, 600 S Paulina St, Suite 765, Chicago, IL, \\ USA
}

We thank Dr. Poulose for his interest in our work. We agree with Dr. Poulose that early use of awake prone positioning should have led to an improvement in the intubation rate. However, as we reported in our study, a higher number of patients in the late awake group (18.2\% vs $7.6 \%)$ died without being intubated [1]. We believe this could have been one of the contributing factors to there being no difference in the intubation rate. We agree with Dr. Poulose that the sample size was not sufficient to detect significant differences of intubation between the early versus late prone positioning group. Future randomized controlled trials are warranted and would address the limitations of our post hoc analysis. Additionally, as this randomized controlled trial [2] was conducted in the original author(s) and the source, provide a link to the Creative Commons licence, and indicate if changes were made. The images or other third party material in this article are included in the article's Creative Commons licence, unless indicated otherwise in a credit line to the material. If material is not included in the article's Creative Commons licence and your intended use is not permitted by statutory regulation or exceeds the permitted use, you will need to obtain permission directly from the copyright holder. To view a copy of this licence, visit http://creativecommons.org/licenses/by/4.0/. The Creative Commons Public Domain Dedication waiver (http://creativeco mmons.org/publicdomain/zero/1.0/) applies to the data made available in this article, unless otherwise stated in a credit line to the data. 
height of the pandemic, there were wide variations in intubation practices $[3,4]$. Due to concerns for aerosol transmission with the use of high flow nasal cannula therapy and non-invasive ventilation, an early intubation strategy was commonly utilized during the initial phase of the study trial. Early intubation may have impacted our ability to truly detect a difference in intubation rate based on the early initiation of awake prone positioning.

\section{Acknowledgements}

None.

\section{Authors' contributions}

The authors read and approved the final manuscript.

\section{Funding}

Not applicable (NA).

\section{Availability of data material}

Not applicable (NA).

\section{Declarations}

Ethics approval

Not applicable (NA).

\section{Consent for publication.}

Not applicable (NA).

\section{Competing interests}

The author declares no competing interests.

Received: 12 November 2021 Accepted: 15 November 2021

Published online: 10 December 2021

\section{References}

1. Kaur R, Vines DL, Mirza S, et al. Early versus late awake prone positioning in non-intubated patients with COVID-19. Crit Care. 2021;25(1):340.

2. Ehrmann S, Li J, Ibarra-Estrada M, et al. Awake prone positioning for COVID-19 acute hypoxaemic respiratory failure: a randomised, controlled, multinational, open-label meta-trial. Lancet Respir Med. 2021;:S2213-2600(21):00356-8.

3. Goyal P, Choi JJ, Pinheiro LC, et al. Clinical characteristics of Covid-19 in New York City. N Engl J Med. 2020;382(24):2372-4.

4. Siempos II, Xourgia E, Ntaidou TK, et al. Effect of early vs. delayed or no intubation on clinical outcomes of patients with COVID-19: An Observational Study. Front Med (Lausanne). 2020;7:614152

\section{Publisher's Note}

Springer Nature remains neutral with regard to jurisdictional claims in published maps and institutional affiliations.

Ready to submit your research? Choose BMC and benefit from:

- fast, convenient online submission

- thorough peer review by experienced researchers in your field

- rapid publication on acceptance

- support for research data, including large and complex data types

- gold Open Access which fosters wider collaboration and increased citations

- maximum visibility for your research: over 100M website views per year

At BMC, research is always in progress.

Learn more biomedcentral.com/submissions 